\title{
WILDFIRE INDUCED CHANGES IN FOREST SOILS IN SOUTHERN CROATIA
}

Ivica KISIĆ $^{1 *}$, Igor BOGUNOVIĆ ${ }^{1}$

\begin{abstract}
This paper presents preliminary results on the alterations in the forest soil properties during an wildfires occurred in 2011 and 2012 in southern Dalmatia (Croatia). At three locations in 2012 different soil samples $(0-5 \mathrm{~cm})$ were taken from shrub lands, depending on vegetation characteristics. Samples were taken from burned and unburned areas in order to determine possible differences. The results showed significant statistical differences between burned and control soil samples for $\mathrm{pH}, \mathrm{EC}$, and several cations and anions $\left(\mathrm{N}_{-} \mathrm{NH}_{4}{ }^{+}, \mathrm{N}-\mathrm{NO}_{3}{ }^{-}, \mathrm{SO}_{4}{ }^{2-}, \mathrm{Ca}^{2+}, \mathrm{K}^{+}\right.$and $\left.\mathrm{Na}^{+}\right)$. These investigated parameters are under the direct influence of fire intensity on the ground. Results show that there is no difference between sites burned in 2011 and those that burned in 2012 . Further investigation will reveal how many years it will take for the soil to return to preburned conditions.
\end{abstract}

Keywords: climate change, wildfire, chemical soil properties, Dalmatian region

\section{INTRODUCTION}

Fire as one of important disturbances in a forest system can alter vegetation composition and even promote tree regeneration (Martínez-Sánchez et al., 1999; Cammeraat and Imeson, 1999). In areas with a Mediterranean climate, they are determinants of landscape structure (Trabaud, 1998). The climatic characteristics of the Mediterranean with warm dry summers and relatively wet winters make it tending to wildfire occurrence. On the other hand, the influence of climatic changes cannot be denied (Pinol et al., 1998; Pausas, 2004). Warm and dry conditions related with global change are expected to increase the area affected by fire in the future (Gillett et al., 2004), and countries in years with the drier summer, have larger burned area that year (Pausas, 2004). Also, 44,000 thunderstorms occur on the earth during any day (Hatten et al., 2005), and in combination with the irresponsible human behaviour makes a huge threat to the natural forest.

\footnotetext{
${ }^{1}$ Department of General Agronomy, Faculty of Agriculture, University of Zagreb, Svetosimunska 25, 10000 Zagreb, Croatia

*Corresponding author: ikisic@agr.hr
} 
In Dalmatian region, for instance, the number of large-scale fires has increased in last 50 years due to socio-economic changes, abandoning livestock raising and rural depopulation and major depopulation of the islands. This has resulted with land abandonment and a forestation with flammable species, that are fire-sensitive (e.g. pine woodlands), and have pushed up highly resilient to fire (shrublands and oak forest).

Forest soil physical and chemical characteristics can be changed during burning, such as soil structure, porosity, $\mathrm{pH}$ and available nutrients. Soil microbial activity and community structure are also bound to be affected by fire (Certini, 2005; Neary et al., 1999). Fire affects soil through its ability to transform soil and ecosystem components. These transformations include outputs in the form of volatilized and combusted material as well as the convection of ash material. Fire can also mineralize organically bound elements such as N, P, and base cations which are then available for uptake by plants or leaching from the soil (DeBano et al., 1998; citation by Hatten et al., 2005). Nevertheless, long-term effects of fire on the soils depend on each soil, its characteristics and the characteristics of the ecological areas.

Many researchers have investigated wildfire and their impact on biological and chemical soils characteristics. Hatten et al. (2005) analyzed pH, C, N and extractable P in Douglas-fir forests of Washington State (USA) on soils affected by fire. Results show very little difference in soil properties between sites burned by low-severity fires and those areas left unburned. And lead to conclusion of little change in soil processes. In contrast to that, Murphy et al. (2006) studied wildfire in Nevada (USA) and concluded that fire and post-fire erosion caused large losses of C, N, P, S, Ca, and $\mathrm{Mg}$ from the forest floor and an increase in $\mathrm{pH}$ in the surface horizon. In Spain Andreu et al. (1996) observed that $\mathrm{K}$ shows low variations after the fire. $\mathrm{pH}$ increased after the fire in the same manner by the mineralization processes and the contribution of ashes, but after a year the values are similar to the previous before the fire.

Nevertheless, ecosystems prone to wildfires may evolve by developing responses to them. Such adaptations include a wide spectrum of strategies, from a partial surviving of the fire to a quick germination by seed or resprouting thereafter. A restoration, at least partial, of $\mathrm{C}$ and $\mathrm{N}$ cycles can be achieved through vegetation regrowth, which can be particularly healthy in Mediterranean ecosystems (Ferran and Vallejo, 1992; Kaye et al., 2010).

The question posed by this paper is: How does the wildfire affect the conditions in soils, and how much time will it take for the properties of fire-affected soils to return to their pre-fire levels? The objective of this study was to evaluate the effect of wildfire on the Mediterranean flora regarding the $\mathrm{pH}$ and $\mathrm{EC}$, as well as different extractable forms of $\mathrm{N}$ $\left(\mathrm{N}-\mathrm{NH}_{4}{ }^{+}, \mathrm{N}^{-\mathrm{NO}_{3}}{ }^{-}\right)$and other ions $\left(\mathrm{SO}_{4}{ }^{2-}, \mathrm{Na}^{+}, \mathrm{K}^{+}, \mathrm{Ca}^{2+}\right)$. The hypothesis that is being put forward is that chemical soil parameters in Dalmatian soil covered by natural flora will vary substantially, and fire disturbances will lead to marked changes. 


\section{MATERIALS AND METHODS}

The study area is located on island Korcula and Peljesac peninsula in the southern Dalmatia $\left(43^{\circ} 02^{\prime}-42^{\circ} 45^{\prime} \mathrm{N}, 16^{\circ} 37^{\prime}-17^{\circ} 46^{\prime}\right.$ E). Climate is Mediterranean and characterized by long, dry and hot summers. Winter is mild and humid. The area is covered with Mediterranean flora, and sometimes pine trees. Flora contains coniferous trees of Aleppo pine (Pinushalepensis), pines (Pinuspinea), Dalmatian black pine (Pinusnigra), cypress (Cypressus sp.) etc. Maki covering part of the area. Samples (uppermost $5 \mathrm{~cm}$ ), in three replicates, were taken with similar aspect, slope, elevation and vegetation characteristics from very healthy shrublands, never cropped, and which have been diversely affected by wildfires in recent decade (areas burned before one or two years). Controls were chosen by their similarity to the burned area in order to determine the differences between samples. The soil $\mathrm{pH}$ was measured using the electrometric method with the Beckman $\mathrm{pH}$-meter $\Phi 72$, in $\mathrm{KCl}$ suspension. Waterextractable anions $\left(\mathrm{F}^{-}, \mathrm{Cl}^{-}, \mathrm{SO}_{4}{ }^{2-}\right)$ and cations $\left(\mathrm{Na}^{+}, \mathrm{K}^{+}, \mathrm{Mg}^{2+}\right)$ in soil samples were extracted in ultra-pure water in 1:10 (w/v) ratio according to ÖNORM L 1092 norm. Observed data were subjected to analysis of variance (ANOVA) using SAS Institute 9.3 and mean values were separated by Fisher's LSD test at $\mathrm{P} \leq 0.05$.

\section{RESULTS AND DISCUSSION}

Statistically significant difference was found in all chemical variables measured in soils that have recently been under fire (burned plots) and those without fire (control plots). Detailed results are presented in Table 1.

Burned soil samples had neutral to alkaline $\mathrm{pH}$ which varied from 6.78 to 7.31 . The median soil $\mathrm{pH}$ for control samples was 6.28 which were $12 \%$ lower than the average in the burned samples. Control samples were low acid to neutral and their soil $\mathrm{pH}$ varied from 5.97 to 6.67. Statistical differences between control and burned samples were observed in the $\mathrm{pH}$ in each location. It is expected that the $\mathrm{pH}$ increases after the fire and decreases over time, the rate at which it does so being dependent on precipitation. Even though the research areas were in the zones of mixed vegetation, forests, and low vegetation, the obtained results confirmed the above assertion. Pereira et al. (2013) found significantly higher $\mathrm{pH}$ values three days after the fire, while Yinghua et al. (2012) have recorded the highest $\mathrm{pH}$ eight months after the fire, after which the $\mathrm{pH}$ started to decrease. The soil $\mathrm{pH}$ values increase as a result of oxidation of soil organic matter by combustion of some organic acids (Certini 2005). Smokvice area burned in 2011 has recorded increased $\mathrm{pH}$ levels, as well as locations burned in 2012. These areas have an uneven precipitation distribution which is reflected in the long spring-summer dry season and rainy winters, and further research should provide insight into the time needed for the soil $\mathrm{pH}$ of return to pre-fire levels.

Burned samples had a higher value of extractable form of $\mathrm{N}$ ions. Significant differences were recorded in $\mathrm{N}^{-\mathrm{NO}_{3}}{ }^{-}$and $\mathrm{NH}_{4}{ }^{+}$in most of investigated locations (Table 1). Higher 
average quantities of $\mathrm{N}-\mathrm{NH}_{4}{ }^{+}$and $\mathrm{N}-\mathrm{NO}_{3}{ }^{-}$were observed in burned samples, with 17.85 $\mathrm{mg} \mathrm{kg}^{-1}$ and $5.58 \mathrm{mg} \mathrm{kg}^{-1}$ and lower in control samples, with 14.80 and $1.55 \mathrm{mg} \mathrm{kg}^{-1}$, respectively. Fire can increase and decrease the amount of $\mathrm{N}$ in soil. Baird (1999) and Binkley et al. (1992) found a small amount of $\mathrm{N}$ in burned soil. Schoch and Binkey (1986) and Yinghua et al. (2012) observed minimal N loss from a fire, but decomposition of the forest floor was stimulated by fire, releasing additional $\mathrm{N}$ during the following growing season, after the regeneration of vegetation. Weston and Attiwill (1990) observed an increase of fire-induced inorganic $\mathrm{N}$ to three times the original concentration over the first 205 days post-fire, but after 485 days the level of $\mathrm{N}$ return to the pre-fire situation. Rovira et al. (2012) in a long-term study of soil after 2 wildfires recorded a $50 \%$ loss of $\mathrm{N}$ (from $0.34 \%$ to $0.17 \%$ ) from the first $5 \mathrm{~cm}$ of soil, but Choromanska and DeLuca (2002) noticed 100\% (from 1.3 to $2.6 \mathrm{~g} \mathrm{~kg}^{-1}$ ) higher N

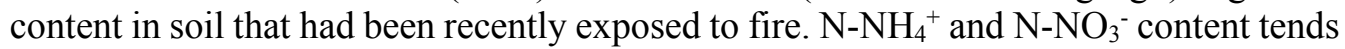
to immediately increase in the soil surface after burning (Wan et al. 2001). N-ion forms rapidly dissipated through plant assimilation and microbial activities, leaching, surface runoff and erosion (Wondzell et al., 2003).

Table 1. Dissolved soil cations and anions for burned and control sample locations (B-burned, C-control)

\begin{tabular}{|c|c|c|c|c|c|c|c|c|c|}
\hline \multirow{2}{*}{\multicolumn{2}{|c|}{ Sample code }} & pH & EC & $\mathrm{N}-\mathrm{NH}_{4}{ }^{+}$ & $\mathrm{N}-\mathrm{NO}_{3}{ }^{-}$ & $\mathrm{SO}_{4}{ }^{2-}$ & $\mathrm{Na}^{+}$ & $\mathbf{K}+$ & $\mathrm{Ca}^{2+}$ \\
\hline & & $-\log \left(\mathbf{H}^{+}\right)$ & $\mu \mathrm{S} \mathrm{cm}{ }^{-1}$ & \multicolumn{6}{|c|}{$m g$ kg$^{-1}$} \\
\hline \multirow{2}{*}{$\begin{array}{l}\text { Korcula } 1 \\
2011\end{array}$} & B & $7.09 \mathbf{a}$ & $266.0 \mathbf{a}$ & $11.30 \mathbf{b}$ & $5.26 \mathbf{a}$ & $52.46 \mathrm{a}$ & $55.42 \mathbf{a}$ & $75.74 \mathbf{a}$ & $542.79 \mathbf{a}$ \\
\hline & C & $6.20 \mathbf{b}$ & $155.9 \mathbf{b}$ & $15.14 \mathbf{a}$ & $0.60 \mathrm{~b}$ & $21.91 \mathbf{b}$ & $44.30 \mathrm{~b}$ & $38.20 \mathrm{~b}$ & $308.53 \mathbf{b}$ \\
\hline \multirow{2}{*}{$\begin{array}{l}\text { Korcula } 2 \\
2012\end{array}$} & B & $6.78 \mathbf{a}$ & $221.0 \mathbf{a}$ & $14.18 \mathbf{a}$ & $7.14 \mathbf{a}$ & $65.97 \mathbf{a}$ & $57.19 b$ & $77.72 \mathbf{a}$ & $381.44 \mathbf{a}$ \\
\hline & C & $5.97 \mathbf{b}$ & $146.5 \mathrm{~b}$ & $12.95 \mathbf{a}$ & $0.28 \mathbf{b}$ & $28.89 \mathbf{b}$ & $67.91 \mathbf{a}$ & $53.56 \mathbf{b}$ & $245.64 \mathbf{b}$ \\
\hline \multirow{2}{*}{$\begin{array}{l}\text { Peljesac } \\
2012\end{array}$} & B & $7.31 \mathbf{a}$ & $335.5 \mathrm{a}$ & $28.06 \mathbf{a}$ & $4.34 \mathbf{a}$ & $327.66 \mathbf{a}$ & $57.17 \mathbf{a}$ & $140.74 \mathbf{a}$ & $607.99 \mathbf{a}$ \\
\hline & C & $6.67 \mathbf{b}$ & $173.5 \mathbf{b}$ & $16.31 \mathrm{~b}$ & $3.77 \mathbf{b}$ & $39.08 \mathbf{b}$ & $42.13 b$ & $27.24 \mathbf{b}$ & $374.96 \mathbf{b}$ \\
\hline
\end{tabular}

*different letters within a row for each location indicate significant differences $(\mathrm{p}<0.05)$

In this study significant differences between burned and control samples were identified in $\mathrm{SO}_{4}{ }^{2-}, \mathrm{Na}^{+}, \mathrm{K}^{+}$and $\mathrm{Ca}^{2+}$, in all investigated locations (Table 1). The amounts of $\mathrm{SO}_{4}{ }^{2-}$ $, \mathrm{Ca}^{2+}, \mathrm{K}^{+}$and $\mathrm{Na}^{+}$were significantly higher in burned samples than in the control. EC also showed significantly higher values in all investigated sites, with almost $58 \%$ higher average value $\left(274.17 \mu \mathrm{S} \mathrm{cm}^{-1}\right)$ in burned than in control samples $\left(158.63 \mu \mathrm{S} \mathrm{cm}^{-1}\right)$. Pereira et al. (2013) also report significantly higher EC and amounts of waterextractable $\mathrm{Ca}^{2+}, \mathrm{Na}^{+}, \mathrm{K}^{+}$and $\mathrm{S}$ in burned samples than in the litter solutions. Sulfur record significant differences between burned and unburnt soil at all locations. Values ranged from 52.46 to $327.66 \mathrm{mg} \mathrm{kg}^{-1}$ at burned plots and from 21.91 to $39.08 \mathrm{mg} \mathrm{kg}^{-1}$ at control plots. Similar to this study Binkley et al. (1992) also finds a smaller amount of sulpfur in the burned samples than in the control. Sulphur cycles may be strongly affected by fire by loosening in gaseous forms (Tiedeman, 1987). The role of $\mathrm{S}$ in 
ecosystem productivity is not well understood, although its fluctuations in the soil appear to parallel that of inorganic N (DeBano, 1991).

Our data are the result of higher soil amount of base cations in burned samples as a consequence of ash material and fire suppression by sea water. There are a number of factors that influence the vulnerability of sites to salinization (Oster $e t$ al., 1996). These factors include the position of a site within a landscape (Manning et al., 2001), soil type and rainfall. Although we don't have particularly rainfall information's at each location and same soil type is dominant in all investigated locations it can be assumed that precipitation rate was similar at each location and was relatively high with $680 \pm 171 \mathrm{~mm}$ (Meteorological and hydrological institute of Croatia, Lastovo station) of rain annually. The annual amount of rain did not reduce the amount of base cations (salt) in the soil, not even in locations that burned two years ago. Furthermore, there is no difference between sites burned in 2011 and those that burned in 2012 (Table 1), although the sites burned in 2011 had one more rainy season. Therefore, it remains to been seen how many years it will take for the soil to return to pre-burned conditions.

\section{CONCLUSIONS}

This preliminary study results show that wildfire led to an important alteration in the chemical composition of the forest soil. Results show difference between burned and control samples at almost all investigate properties. Burned soil samples have been recorded higher values of $\mathrm{pH}, \mathrm{EC}, \mathrm{SO}_{4}^{2-}, \mathrm{Ca}^{2+}, \mathrm{K}^{+}$and $\mathrm{Na}^{+}$. Burned samples also record a higher value of extractable form of $\mathrm{N}$ ions. Such changes, from these fires, in soil properties from fire suppression suggest there has also been change in soil processes. Furthermore, differences between plots that was burned in 2011 and those that was burned in 2012 were small and led to conclusion that is more than two rainy winter season necessary for returning chemical properties in pre-burned levels and hence warrants further investigation.

\section{REFERENCES}

Andreu, V., Rubio, J.L., Forteza, J., Cerni, R. 1996. Postfire Effects on Soil Properties and Nutrient Losses. International Journal of Wildland Fire, 6(2): 53-58. DOI: 10.1071/WF9960053

Baird, M, Zabowski, D, Everett, R.L. 1999. Wildfire effects on carbon and nitrogen in inland coniferous forests. Plant Soil, 209: 233-243. DOI: 10.1023/A:1004602408717

Binkley, D., Richter, D., David, M.B., Caldwell, B. 1992. Soil chemistry in a loblolly/long leaf pine forest with interval burning. Ecological Applications, 2(2): 157-164. DOI: $10.2307 / 1941772$

Cammeraat, L.H.,. Imeson, A.C. 1999. The evolution and significance of soil-vegetation patterns following land abandonment and fire in Spain, the significance of soil, water 
and landscape processes in banded vegetation patterning. Catena, 37(1-2): 107-127. DOI: 10.1016/S0341-8162(98)00072-1

Certini, G. 2005. Effects of fire on properties of forest soils: a review. Oecologia, 143(1): 1-10. DOI: $10.1007 / \mathrm{s} 00442-004-1788-8$

Choromanska, U., DeLuca, T.H. 2002. Microbial activity and nitrogen mineralization in forest mineral soils following heating: evaluation of post-fire effects. Soil Biology and Biochemistry, 34(2): 263-271. DOI: 10.1016/S0038-0717(01)00180-8

DeBano, L.F. 1991. The effect of fire on soil properties. In Proceedings management and productivity of western-Montane. Forest Soils, pp. 151-155.

DeBano, L.F., Neary, D.G., Ffolliott, P.F., 1998. Fire's Effects on Ecosystems. Wiley, New York.

Ferran, A., Vallejo, V.R., 1992. Litter dynamics in post-fire successional forests of Quercus ilex. Vegetatio, 99(1): 239-246. DOI: 10.1007/BF00118230

Gillett, N.P., Weaver, A.J., Zwiers, F.W., Flannigan, M.D., 2004. Detecting the effect of climate change on Canadian forest fires. Geophysical Research Letters, 31(18): L18211. DOI: 10.1029/2004GL020876

Hatten, J., Zabowski, D., Scherer, G., Dolan, E. 2005. A comparison of soil properties after contemporary wildfire and fire suppression. Forest Ecology and Management, 220: 227-241. DOI: 10.1016/j.foreco.2005.08.014

Kaye, J.P., Romanyà, J., Vallejo, V.R. 2010. Plant and soil carbon accumulation following fire in Mediterranean woodlands in Spain. Oecologia, 164: 533-543. DOI: $10.1007 / \mathrm{s} 00442-010-1659-4$

Manning, G., Fuller, L.G., Eilers, R.G., Florinsky, I. 2001. Topographic influence on the variability of soil properties within an undulating Manitoba landscape. Canadian Journal of Soil Science, 81(4): 439-447. DOI: 10.4141/S00-057

Martínez-Sánchez, J.J., Ferrandis, P., de las Heras, J., Herranz, J.M. 1999. Effect of burntwood removal on the natural regeneration of Pinus halepensis after fire in a pine forest in Tusvalley (SE Spain). Forest Ecology and Management, 123(1): 110. DOI: $10.1016 / \mathrm{S} 0378-1127(99) 00012-2$

Murphy, J.D., Johnson, D.W., Miller, W.W., Walke,r R.F., Carroll, E. F., Blank, R.R. 2006. Wildfire Effects on Soil Nutrients and Leaching in a Tahoe Basin Watershed. Journal of Environmental Quality, 35(2): 479-489. DOI: $10.2134 /$ jeq2005.0144

Neary, D.G., Klopatek, C.C., DeBano, L.F., Ffolliott, P.F. 1999. Fire effects on below ground sustainability: a review and synthesis. Forest Ecology and Management, 122(1-2): 51-71. DOI: 10.1016/S0378-1127(99)00032-8

Oster, J.D., Shainberg, I., Abrol, I.P. 1996. Reclamation of salt-affected soil. In: Soil Erosion, Conservation and Rehabilitation (Ed: Agassi, M). Marcel Dekker, New York, pp. 315-351. 
Pausas, J.G. 2004. Changes in fire and climate in the eastern Iberian Peninsula (Mediterranean basin). Climatic Change, 63: 337-350. DOI:10.1023/ B:CLIM.0000018508.94901.9C

Pereira, P., Úbeda, X., Martin, D., Mataix-Solera, J., Cerdà, A., Burguet, M. 2013. Wildfire effects on extractable elements in ash from a Pinuspinaster forest in Portugal. Hydrological Processes. DOI: 10.1002/hyp.9907

Piñol, J., Terradas, J., Lloret, F. 1998. Climate warming, wildfire hazard, and wildfire occurrence in coastal eastern Spain. Climatic Change, 38: 345-357. DOI:10.1023/A:1005316632105

Rovira, P., Romanyà, J., Duguy, B. 2012. Long-term effects of wildfires on the biochemical quality of soil organic matter: A study on Mediterranean shrublands. Geoderma, 179: 9-19. DOI: 10.1016/j.geoderma.2012.02.011

Schoch, P., Binkley, D. 1986. Prescribed burning increased nitrogen availability in a mature loblolly pine stand. Forest Ecology and Management, 14(1): 13-22. DOI: 10.1016/0378-1127(86)90049-6

Tiedemann, A.R. 1987. Notes: Combustion Losses of Sulfur from Forest Foliage and Litter. Forest Science, 33(1): 216-223.

Trabaud, L., 1998. Are wildland fires threatening the Mediterranean flora and vegetation? In: Advances in Ecological Sciences. Ecosystems and Sustainable Development (Eds: Uso, L.J., Brebbia, C.A., Power, H.), vol. 1. Computational Mechanics Publications, Southampton, UK, pp. 137-146.

Wan, S.Q., Hui, D.F., Luo, Y.Q. 2001. Fire effects on nitrogen pools and dynamics in terrestrial ecosystems: A meta-analysis. Ecological Applications, 11: 1349-1365. DOI: 10.1890/1051-0761(2001)011[1349: FEONPA] 2.0.CO;2

Weston, C.J., Attiwill, P.M. 1990. Effects of fire and harvesting on nitrogen transformations and ionic mobility in soils of Eucalyptus regnans forests of southeastern Australia. Oecologia, 83(1): 20-26. DOI: 10.1007/BF00324628

Wondzell, S.M., King, J.G. 2003. Post-fire erosional processes in the Pacific Northwest and Rocky Mountain region. Forest Ecology and Management, 178: 75-87. DOI: 10.1016/S0378-1127(03)00054-9

Yinghua, X., Jian, S., Qing, L., Jing, M., Yingwu, S., Kai, L. 2012. Effects of a surface wildfire on soil nutrient and microbial functional diversity in a shrubbery. Acta Ecologica Sinica, 32(5): 258-264. DOI: 10.1016/j.chnaes.2012.07.007 